\title{
Local populations of endangered Maculinea (Phengaris) butterflies are flood resistant
}

\author{
Joanna Kajzer-Bonk • Piotr Nowicki • \\ Maciej Bonk • Piotr Skórka • Magdalena Witek • \\ Michał Woyciechowski
}

Received: 18 January 2013/ Accepted: 29 August 2013/Published online: 4 September 2013

(C) The Author(s) 2013. This article is published with open access at Springerlink.com

\begin{abstract}
Semi-natural wet meadows are threatened by drainage, the abandonment of traditional management and climate change. The large blue butterflies Maculinea teleius and $M$. nausithous are flagship species associated with wet meadows and are the targets of many conservation programmes. However, there is little knowledge on the impact of natural catastrophes, such as floods, on the persistence of these butterflies. In our study we tested how a flood that resulted in the temporary inundation of meadows affected populations of M. teleius and M. nausithous. Studies were conducted in two consecutive seasons of 2009 (with 'normal' weather) and 2010 (with extreme rainfall and a consequent flood in May) in a wet meadow complex located in the Vistula River valley in southern Poland. In both years the abundance of adults was estimated for each local habitat patch $(\mathrm{n}=55)$ within sympatric metapopulations of both species. Additionally, in June 2010, i.e. directly after the flood and shortly before the flight period, a total of 754 Myrmica ant nests in 10 habitat patches (6 inundated vs. 4 not inundated) were checked for the presence of Maculinea
\end{abstract}

J. Kajzer-Bonk ( $₫)$ · P. Nowicki · M. Woyciechowski Institute of Environmental Sciences, Jagiellonian University, Gronostajowa 7, 30-387 Kraków, Poland

e-mail: joanna.kajzer@uj.edu.pl

\section{Bonk}

Department of Entomology, Institute of Zoology, Jagiellonian University, Gronostajowa 9, 30-387 Kraków, Poland

\section{P. Skórka}

Institute of Zoology, Poznań University of Life Sciences,

Wojska Polskiego 71C, 60-625 Poznan, Poland

M. Witek

Museum and Institute of Zoology, Polish Academy of Science, Wilcza 64, 00-679 Warsaw, Poland larvae and pupae. We found no impact of inundation on year-to-year changes in adult population sizes. The probability of occurrence of Maculinea larvae and pupae in ant nests was higher in temporarily inundated meadows. Our results indicate that temporary inundation occurring after long-term downpours does not negatively affect the investigated species even during the larval period in ant nests at ground level. This provides an argument against drainage works in wet meadows with Maculinea butterflies.

Keywords Habitat management - Inundation . Myrmica ants · Natural catastrophes · Weather · Wet meadows

\section{Introduction}

Most recent climate change models predict that extreme weather events such as flooding or long periods of drought will become more frequent in the near future (Cowie 2007; Fronzek et al. 2012). Global changes interplay with human activities such as intensification of land-use practices, development of urban areas and land drainage, all contributing to the alteration and/or loss of semi-natural habitats and species occurring in them (Benton et al. 2003; Settele et al. 2008). Wet meadows are an example of semi-natural habitats characterised by high biotic diversity, including rare butterfly species, and are particularly vulnerable to environmental changes (Maes and Van Dyck 2001; Robinson and Sutherland 2002; Saarinen et al. 2003; Van Buskirk and Willi 2004). Butterflies, with their typically specialised and rather sedentary larval stages, are sensitive to the condition of their habitats and this makes them good indicators of ecosystem changes. Nevertheless, there is still little knowledge about the impact of extreme weather events on 
local butterfly populations and more studies are required (Gibbs et al. 2011).

Studies on several wet meadow species revealed differing responses to floods. There is a generally positive correlation between submergence time and mortality, however, different species are resistant to submergence to a varying extent (Joy and Pullin 1997, 1999; Konvička et al. 2002; Webb and Pullin 1998). However, Truxa and Fiedler (2012) did not detect a negative impact of floods on moth assemblages, even in the case of species whose caterpillars live at the ground level. Moreover, the immature life stage of overwintering butterflies may be key to survival during flooding: while non-mobile Lycaena xanthoides eggs (Severns et al. 2006) or Neptis rivularis hibernacula (Konvička et al. 2002) experience relatively high mortality during flooding, Lycaena dispar batavus second instar larvae do not (Webb and Pullin 1998).

Maculinea (= Phengaris) teleius (Bergsträsser, 1779) and M. nausithous (Bergsträsser, 1779) with IUCN threat criteria Lower Risk/near threatened (IUCN 2012) are considered as useful indicators of grassland biodiversity (Settele et al. 2005). Moreover, they have become flagship species for nature conservation, especially in EU countries (Thomas and Settele 2004; Thomas et al. 2009). Both species occur in wet meadows and are threatened by anthropogenic impacts, such as fragmentation, abandonment of traditional management and drainage works (Batáry et al. 2009; Dierks and Fischer 2009; van Swaay et al. 2010; van Swaay 2012). On the other hand, under natural conditions Maculinea populations are remarkably stable (Nowicki et al. 2005b, c), and unlike many other butterfly species their dynamics are weakly influenced by weather patterns (Nowicki et al. 2009). Obviously, this does not preclude their possible vulnerability to extreme weather events. In particular, since Maculinea larvae spend 11-23 months living as parasites in Myrmica ant nests at ground level (Elmes et al. 1998; Tartally and Varga 2008; Thomas 1984; Thomas et al. 1989; Witek et al. 2006, 2010), they are occasionally exposed to temporary inundation due to heavy rainfall and/or floods.

To our knowledge, however, there have been no attempts at examining the effects of floods on Maculinea. Our aim was thus to test how a flood that resulted in temporary inundation of meadows affected populations of M. teleius and M. nausithous. We focused on year-to-year changes in adult numbers as well as on larval survival in ant nests by taking advantage of a flood that occurred in our study region in the spring of 2010 .

\section{Materials and methods}

Study sites

The study was conducted in 2009 and 2010 within a large meadow complex located in the Vistula River valley in
Kraków, southern Poland $\left(50^{\circ} 01^{\prime} \mathrm{N}, 19^{\circ} 54^{\prime} \mathrm{E}\right.$, Fig. 1). The meadows include 55 patches (size range: $0.01-33$ ha; total area ca. 200 ha) with Sanguisorba officinalis, which is the foodplant as well as the primary nectar source of both $M$. teleius and M. nausithous (Thomas 1984; Thomas et al. 1998). All patches are inhabited by local populations of both species. They form classic metapopulations, with local populations acting as independent demographic units: neither local abundances nor their year-to-year changes show any spatial autocorrelation (Nowicki et al. 2007; see also Nowicki and Vrabec 2011). Nevertheless, local extinctions occur only sporadically and patch occupancy reaches $94-100 \%$ in any given year (Nowicki et al. 2007; authors' unpubl. data).

The flood in the Vistula river basin began on May 17, 2010 during heavy rainfall with total precipitation of $146 \mathrm{~mm}$ in that month (http://www.pogoda.ekologia.pl/Archiwum/ Archiwum_pogody/Krakow.2010-05-16). Although our study area is protected by a system of embankments and thus was spared by the main flood wave from the Vistula, local tributaries overflowed and submerged adjacent meadows. The water typically reached $20-30 \mathrm{~cm}$ in depth and remained on the meadows for about 3 weeks, although water remained in ground hollows until mid August.

Virtually all the Maculinea habitat patches within the study area were affected by the flood, although to a highly varying degree. Regretfully, we were not able to quantity the extent of inundation (e.g. water depth, inundated area, duration, etc.) due to safety and logistic reasons. Therefore, flood impact was assessed through hydrological modelling conducted using the GIS Idrisi software (Eastman 1997). We applied the Topmodel (Beven and Kirkby 1979; see this reference for the detailed description of the model), which represents a well-established standard for modelling basin hydrology, based on its topography (Pan et al. 2004). Due to the lack of fine-scale data we assumed for simplicity that the rainfall was uniform across the area, and that the soil was able to store one third of the rainfall. The former assumption is reasonable, concerning relatively small spatial dimensions of the study area $(5 \times 7 \mathrm{~km})$, and the latter is concordant with our personal observations that the first inundations occurred ca. $24 \mathrm{~h}$ after the start of ca. 72-h downpour. With the model applied, we were able to estimate the proportion of overflown area (precisely "saturated area with overland flow", following the Topmodel terminology) for each habitat patch, which was subsequently used as a proxy of inundation extent.

Testing the response of adult populations to flooding

Local population sizes of M. teleius and M. nausithous have been continuously monitored since 2003 , and were assessed with the catch per-time-unit method conducted 
Fig. 1 Map of local populations of $M$. teleius and $M$. nausithous occupying Sanguisorba officinalis patches (grey polygons) in the Kraków region, southern Poland. Symbols indicate inundated (I1-I6) and not inundated patches $(\mathrm{C} 1-\mathrm{C} 4)$, in which ant nests were surveyed (see Table 1 for details). Solid lines represent water courses, both natural (streams) and artificial ones (ditches)

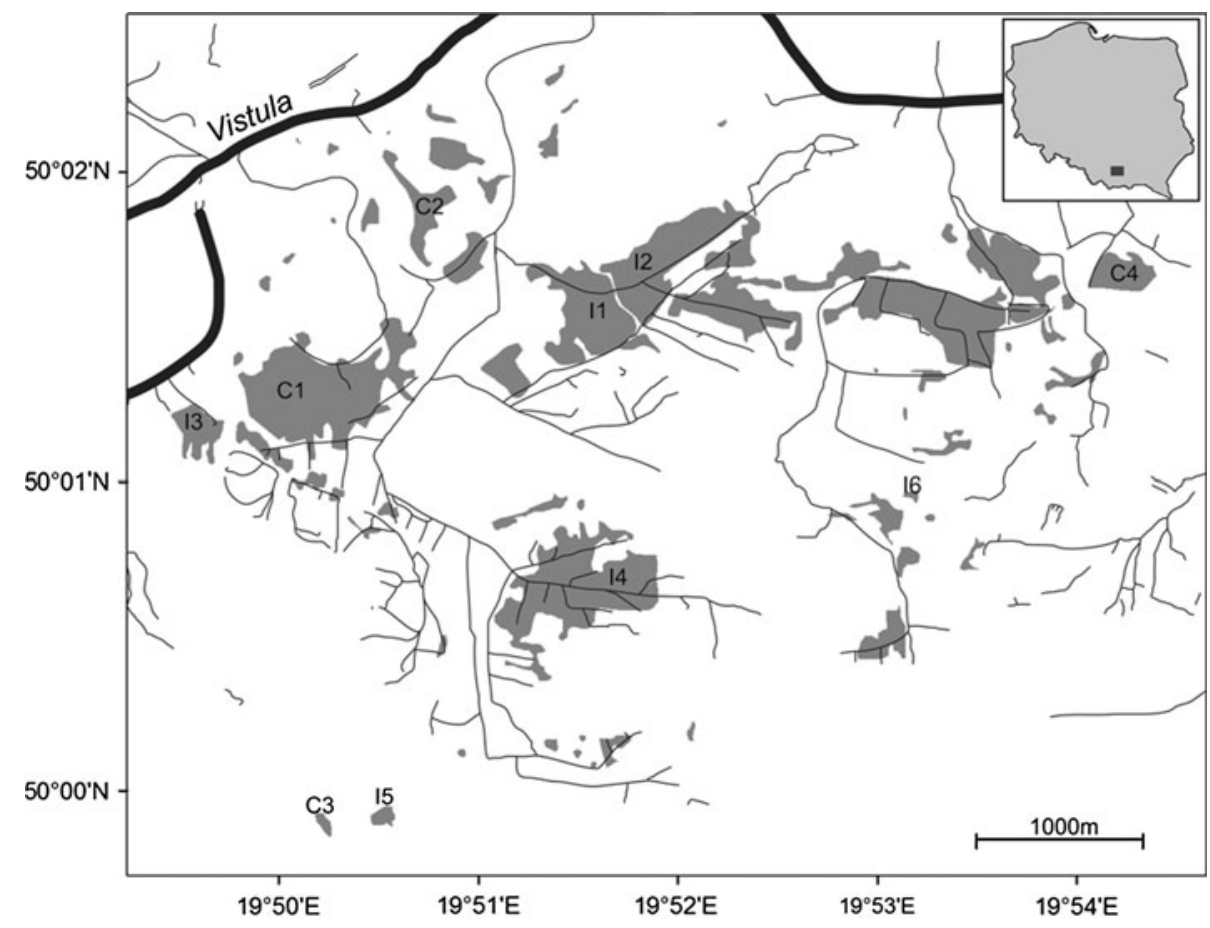

during peak occurrence of adult butterflies in late July each year. This method allows the estimation of peak population sizes which are subsequently extrapolated into seasonal population sizes using the method described by Nowicki et al. (2005a), which was tested and parameterised at the patches intensively investigated with mark-recapture surveys (Nowicki et al. 2005a, 2007). The estimates yielded by the catch-per-time-unit method proved to be highly concordant with those derived with mark-release-recapture for intensively studied patches (Nowicki et al. 2007).

A generalized linear model (GLM) with binomial error variance and logit-link function was applied to evaluate the impact of inundation index, on the increase or decrease of abundances of butterflies in local populations, separately for M. teleius and M. nausithous. The dependent variable was then coded as a binary variable with " 0 " assigned for local populations that increased and " 1 " for local populations that decreased between 2009 and 2010 .

A GLM with Gaussian error and identity-link function was applied to evaluate the impact of flooding on magnitude of year-to-year population size change, separately for M. teleius and M. nausithous. The proportional year-toyear change in population size (population size in 2010 divided by size in 2009) was used as the dependent variable. Several patches lacking a local population in 2009 were removed from the analysis, and thus the sample sizes comprised 52 and 53 patches for M. teleius and M. nausithous, respectively. The explanatory variable in the above analyses was the inundation extent derived with the
Topmodel. The analyses were performed using IBM SPSS Statistics version 19.0.0 (SPSS Inc. 2010).

Testing the response of larvae in ant nests to flooding

In June 2010, directly after the flood and shortly before the flight period of both investigated species, ten habitat patches were selected to check for the impact of inundation on the presence and abundance of Maculinea larvae and pupae in Myrmica ant nests (Fig. 1). Six patches had been previously entirely under water for ca. 3 weeks, while the remaining were hardly at all inundated. We looked for Myrmica ant nests within a distance of $2 \mathrm{~m}$ from foodplants. This procedure ensured that all nests found could potentially be infested because a $2-\mathrm{m}$ radius around foodplants is a typical foraging range for Myrmica ants, within which they bring Maculinea larvae to their nests (Elmes et al. 1998). Search effort was standardised across patches and constituted about $6 \mathrm{~h}$ per 100 nests in a patch by three persons. Randomly selected ant nests were opened and examined for Maculinea larvae and pupae. Since the study period corresponded to the time when fourth-instar larvae or pupae stay in the upper parts of ant nests or in brood chambers, they were relatively easy to find. Larvae of $M$. teleius and M. nausithous were identified using the key by Śliwińska et al. (2006); however species identification was impossible in the case of pupae.

In order to quantify potential differences in the species composition of putative host ants (M. scabrinodis, M. rubra, 
M. ruginodis, $M$. tulinae) among the investigated habitat patches, we obtained ant workers from a random sample of 439 nests and preserved them in $72 \%$ alcohol for further laboratory identification using the key by Czechowski et al. (2002). The relative nest frequencies of potential host ant species did not differ between inundated and not inundated patches (Mann-Whitney $U$ test, $P_{M}$. rubra $=0.7237$; $P_{M . \text { scabrinodis }}=0.2888 ; P_{M . \text { ruginodis }}=0.4795 ; P_{M \text {. tulinae }}=$ 0.7246).

The effect of inundation on Maculinea larvae and pupae presence in host ant nests was analysed using a generalized linear mixed model (GLMM) with binomial error variance and the logit-link function. Patch fate (inundated or not inundated), ant species and log transformed habitat patch area were applied as independent factors, while Maculinea absence/presence constituted a $0-1$ dependent variable. Patch identity (ID) was adopted as a random factor. Since M. teleius and M. nausithous pupae are indistinguishable (Śliwińska et al. 2006), in the first step the data on larvae and pupae of both species were pooled together to check if inundation influenced the chances of Myrmica nests being infected by either Maculinea species. Next, we analysed the impact of inundation separately for the presence of $M$. teleius and M. nausithous larvae. Again, all interaction terms of fixed factors were excluded from the final models if non-significant. The data collected have obvious limitations resulting from the fact that there is no complete data of ant species composition for some of the studied meadows. For this reason we also conducted the second analysis in which all the ant nests were pooled together, and the 'ant species factor' was not considered.

In addition, we compared the abundance of Maculinea larvae in infested nests between inundated and not inundated patches using GLMM with negative binomial error variance and log-link function. The structure of the model was analogous to that for the presence of larvae and pupae in ant nests.

\section{Results}

Overall metapopulation size was estimated at $73 \pm 9$ thousand $(N \pm \mathrm{SE})$ M. teleius adults and $64 \pm 11$ thousand M. nausithous adults in 2009. In the following year, i.e. after the flood, it remained at the same level, $74 \pm 7$ thousand adults in M. teleius, but decreased to $41 \pm 5$ thousand adults in M. nausithous. While the change in the latter species may suggest a negative effect of flooding at first glance, it reflected typical year-to-year fluctuations in butterfly numbers. More importantly, it was in fact mostly caused by the sharp drop recorded in the single largest local population which in 2009 peaked at 21.5 thousand adults, i.e. by far the highest number recorded over a 10-year monitoring period, and in the following year it returned to the normal level of 3.5 thousand adults (open squares in Fig. 2). It has to be emphasized that this particular population occupies a patch that was spared by flooding $(\mathrm{C} 1$ in Table 1). Altogether, 27 local populations of M. teleius increased and 25 decreased in size from 2009 to 2010 and the decrease or increase was not related to inundation index (GLM $\left.F_{1,48}=1.261, P=0.267\right)$. For $M$. nausithous, 22 and 31 local populations increased and decreased in size, respectively, but these changes were again not related to inundation index (GLM $\left.F_{1,49}=0.161, P=0.690\right)$. Similarly, magnitude of year-to-year changes in local population sizes was not related to inundation extent in both $M$. teleius (GLM $F_{1,50}=0.125, P=0.725$ ) and $M$. nausithous (GLM $\left.F_{1,51}=0.427, P=0.516\right)$.

We examined 754 Myrmica ant nests and found 133 of them infested by Maculinea: 120 within inundated patches and 13 within not inundated patches (Table 1). None of factors affected occurrence of Maculinea larvae or pupae in the model with the ant species factor (Table 2a). When larger sample size was analysed (but excluding the 'ant species' factor), the probability of occurrence of Maculinea larvae or pupae in ant nests was-somewhat surprisinglysignificantly higher in inundated patches (Table 2b; Fig. 3). Patch area did not correlate with Maculinea occurrence in ant nests (Table 2b; Fig. 3). Separate analyses for larvae of both butterfly species revealed that $M$. teleius larvae occurred in a larger proportion of ant nests in inundated patches as compared with not inundated patches (Table 2b). In the case of M. nausithous this relationship was non-significant (Table 2b). However, the sample of analysed M. nausithous larvae was much smaller which have reduced the power of the tests applied and might have

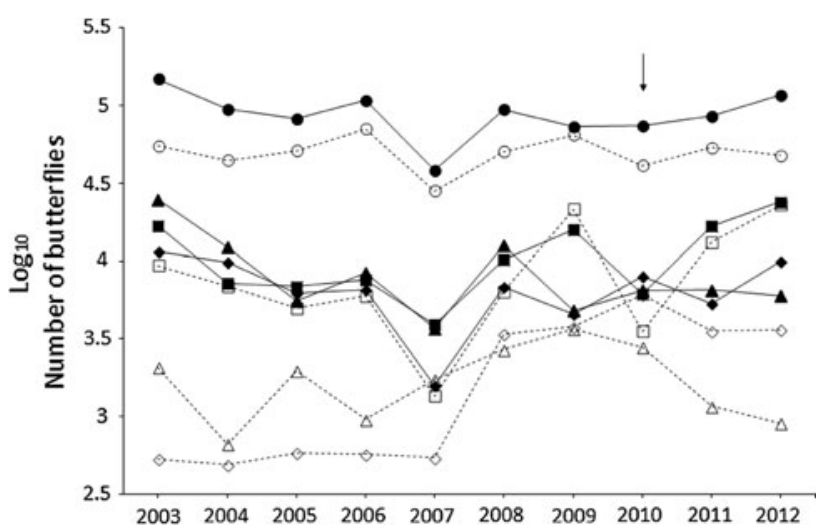

Fig. $2 \log _{10}$-transformed numbers of adult Maculinea teleius (solid symbols and lines) and M. nausithous (open symbols and dashed lines) butterflies in 2003-2012. Total metapopulation sizes (circles) and three the largest local populations (triangles, squares and diamonds) are presented. The remaining populations (not included for the sake of clarity) showed similarly chaotic fluctuations. Arrow indicates a year with floods 
Table 1 Numbers of Maculinea larvae and pupae found in the investigated habitat patches

\begin{tabular}{|c|c|c|c|c|c|c|c|}
\hline Patch ID & $\begin{array}{l}\text { Patch } \\
\text { area } \\
\text { (ha) }\end{array}$ & $\begin{array}{l}\text { Number } \\
\text { of nests } \\
\text { checked }\end{array}$ & $\begin{array}{l}\text { Number } \\
\text { (proportion) of } \\
\text { infested nests }\end{array}$ & $\begin{array}{l}\text { Number of } \\
\text { larvae and pupae } \\
\text { (per } 100 \text { nests) }\end{array}$ & $\begin{array}{l}\text { Number of } \\
\text { M. teleius larvae } \\
\text { (per } 100 \text { nests) }\end{array}$ & $\begin{array}{l}\text { Number of } \\
\text { M. nausithous larvae } \\
\text { (per } 100 \text { nests) }\end{array}$ & $\begin{array}{l}\text { Number of } \\
\text { pupae } \\
\text { (per } 100 \text { nests) }\end{array}$ \\
\hline I1 & 20.0 & 100 & $33(33.0)$ & $58(58)$ & 29 (29) & 19 (19) & $10(10)$ \\
\hline I2 & 26.5 & 99 & $39(39.4)$ & $72(78)$ & $72(73)$ & $0(0)$ & $0(0)$ \\
\hline I3 & 6.2 & 103 & $22(21.4)$ & $58(56)$ & $43(42)$ & $11(11)$ & $4(4)$ \\
\hline I4 & 27.4 & 50 & $5(10.0)$ & $6(12)$ & $2(4)$ & $0(0)$ & $4(8)$ \\
\hline I5 & 1.1 & 50 & $4(8.0)$ & $8(16)$ & $1(2)$ & $5(10)$ & $2(4)$ \\
\hline I6 & 0.4 & 100 & $17(17.0)$ & $41(41)$ & $18(18)$ & $2(2)$ & $21(21)$ \\
\hline $\mathrm{C} 1$ & 33.3 & 50 & $2(4.0)$ & $2(4)$ & $0(0)$ & $0(0)$ & $2(4)$ \\
\hline $\mathrm{C} 2$ & 3.5 & 51 & $3(5.9)$ & $3(6)$ & $0(0)$ & $0(0)$ & $3(6)$ \\
\hline $\mathrm{C} 3$ & 0.6 & 50 & $2(4.0)$ & $3(6)$ & $2(4)$ & $0(0)$ & $1(2)$ \\
\hline $\mathrm{C} 4$ & 4.1 & 101 & $6(5.9)$ & $6(6)$ & $2(2)$ & $1(1)$ & $3(3)$ \\
\hline
\end{tabular}

I1-I6 represent patches inundated in spring 2010, whereas C1-C4 are not inundated patches

affected their outcome. Abundance of Maculinea larvae or pupae was not affected by inundation but increased with patch area (Table 2c).

\section{Discussion}

Our results suggest that there was no negative impact of the flood in the spring 2010 on the investigated local populations of Maculinea butterflies. The M. teleius larval infestation rate in ant nests, a key parameter for Maculinea population dynamics (Hochberg et al. 1994), was actually higher in the temporarily inundated habitat patches if the 'ant species' factor was excluded from the model. Clearly, this finding does not necessarily imply larger larval populations therein, because it may be accounted for by potential differences in Myrmica ant nest densities that we did not estimate (although it should be noted that search effort was standardised across patches). For instance, we

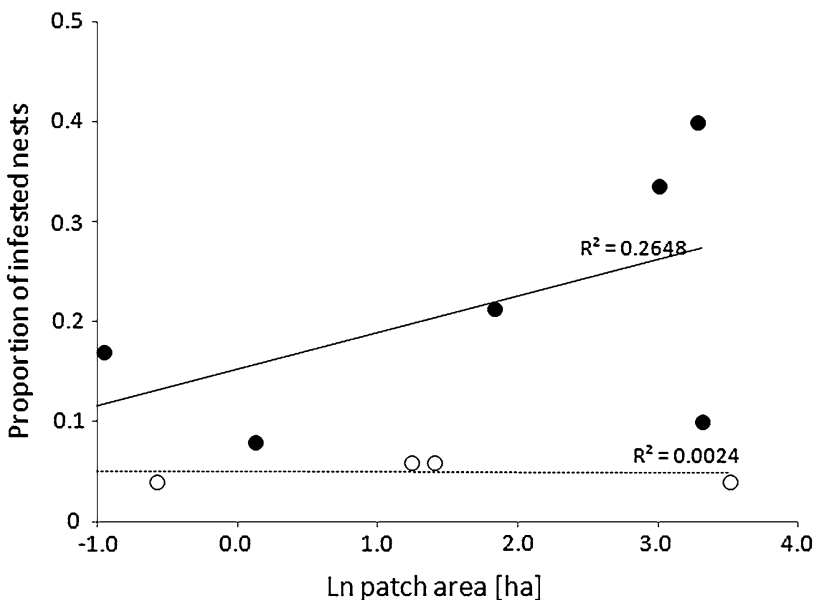

Fig. 3 Proportion of Myrmica ant nests infested by Maculinea larvae or pupae in inundated (solid dots) and not inundated patches (empty dots). Regression lines for inundated (solid line) and not inundated patches (dashed line) are presented together with their respective fractions of explained variation $\left(R^{2}\right)$

Table 2 Results of the generalized linear mixed model for factors affecting the occurrence (with factor 'ant species' (a) and without factor 'ant species' (b)) and abundance (c) of Maculinea larvae or pupae in host ant nests

\begin{tabular}{|c|c|c|c|c|c|c|c|c|c|}
\hline \multirow[t]{2}{*}{ Factor } & \multicolumn{3}{|c|}{ Maculinea larvae and pupae pooled } & \multicolumn{3}{|c|}{ M. teleius larvae } & \multicolumn{3}{|c|}{ M. nausithous larvae } \\
\hline & $d f$ & $F$ & $P$ & $d f$ & $F$ & $P$ & $d f$ & $F$ & $P$ \\
\hline \multicolumn{10}{|l|}{ (a) } \\
\hline Inundation & 1,421 & 0.000 & 0.994 & 1,421 & 0.000 & 0.996 & 1,421 & 0.141 & 0.707 \\
\hline Ln area & 1,421 & 0.299 & 0.585 & 1,421 & 0.582 & 0.446 & 1,421 & 0.154 & 0.695 \\
\hline Ant species & 3,421 & 1.642 & 0.179 & 3,421 & 1.470 & 0.222 & 1,421 & 0.094 & 0.963 \\
\hline \multicolumn{10}{|l|}{ (b) } \\
\hline Inundation & 1,751 & 10.980 & 0.010 & 1,731 & 6.433 & 0.011 & 1,731 & 2.396 & 0.122 \\
\hline Ln area & 1,751 & 1.600 & 0.206 & 1,731 & 0.234 & 0.629 & 1,731 & 0.057 & 0.812 \\
\hline \multicolumn{10}{|l|}{ (c) } \\
\hline Inundation & 1,110 & 2.988 & 0.087 & 1,91 & 1.979 & 0.163 & 1,24 & 0.260 & 0.615 \\
\hline Ln area & 1,110 & 6.008 & 0.016 & 1,91 & 1.038 & 0.311 & 1,24 & 0.776 & 0.387 \\
\hline
\end{tabular}

Significant results $(P<0.05)$ are highlighted in bold 
cannot exclude the possibility that the higher larval infestation rate in inundated patches stems from a higher proportion of small ant nests eliminated by the inundations. Small ant nests are less likely to support Maculinea larvae (Witek et al. 2006, 2010). Admittedly, the comparison of infestation rate in a single season between inundated and non-inundated meadows does not constitute a proper experimental design, because the sites may also differ in other environmental characteristics affecting the chances of Maculinea larvae survival in ant nests (e.g. soil conditions). Nevertheless, it is worth noting that the outcome of our analysis of larval occurrence is consistent with the results of those concerning adult butterfly populations.

Most importantly, local adult populations did not decrease in the year when inundation took place. In contrast, WallisDeVries (2004) detected a negative impact of floods on Dutch populations of M. alcon. In our study area M. alcon co-occurs with M. teleius and M. nausithous, even their larvae are frequently found together in the same ant nests, which may suggest similar habitat requirements and resistance to flood. The discrepancy between the Dutch study and our results may reflect different characteristics of floods in both regions rather than ecology of the species. Possibly, flood water is deeper and resides for a longer duration on the low-lying floodplains of the Netherlands as compared to our study area. In addition, it cannot be excluded that geographical differences in habitat requirements of Maculinea butterflies may be responsible for the discrepancy between the results obtained in the Netherlands and Poland. Unfortunately, there is no available data to resolve this interesting problem.

Generally inundation is regarded as a harmful process for most grassland invertebrates due to strong alteration (at least temporarily) of habitats (Plum 2005). Simultaneously, insect larval stages seem to be the most resistant to local inundation (Plum 2005). Historically, the ground water level in our study area fluctuated between -2 and $0 \mathrm{~m}$, but management and drainage works have led to its decrease (Pociask-Karteczka 1994). Moreover, metapopulations of the investigated butterflies have been historically exposed to relatively frequent floods occurring on average once per decade (data from the seventeenth to twentieth centuries; Bielański 1997), and thus they may have adapted to survive such events (Nichols and Pullin 2000). Moreover, local and small-scale water level fluctuations in meadows rarely lead to the entire patch area being covered by water. At our sites, despite an often extensive area of inundation, the water level did not cover high Carex sp. or Molinia sp. clumps which thus might have acted as refuges for ants.

Since our study suggests that temporary inundation does not affect Maculinea butterflies negatively, it is worth considering the possible benefits of floods. Occasional flooding increases soil humidity which may be profitable for many wet meadow species. In particular, Batáry et al. (2007) found that soil humidity was one of the best predictors for M. teleius presence in a mosaic landscape in Hungary. Moreover, soil moisture is an important factor shaping ant assemblages (Baccaro et al. 2010). Thus, temporary flooding can possibly stabilise host ant communities. In addition, flooding may benefit plant communities of wet meadows. Although shrubs and young trees are likely to suffer from inundation, herbaceous plants have developed strategies for successful reproduction in occasionally flooded areas (Burmeier et al. 2010). In this way floods may prevent or at least slow down succession on abandoned meadows. Moreover, it has been demonstrated that seed banks in flooded meadows are particularly rich in seeds of rare and endangered species (Hölzel and Otte 2004).

Our findings offer conservationists and land managers an argument against the drainage of wet meadows. For several decades drainage programmes have been enforced in Central Europe, mainly as efforts to increase the area of arable land or as flood prevention measures. This has decreased ground water level and often led to meadow desiccation (Kowalska 2009). The investigated butterflies are well adapted to living in wet meadows, thus short-term inundation after heavy rainfall may be potentially helpful to restore the formerly drained and desiccated habitats.

Acknowledgments The study was funded by the Polish Ministry of Science and Higher Education grant N N304 064139, the German Federal Ministry of Education and Research within its FP6 BiodivERsA Eranet project CLIMIT, the EU FP7 SCALES program ("Securing the Conservation of biodiversity across Administrative Levels and spatial, temporal and Ecological Scales"; project \#22685) and by the Jagiellonian University under grant DS/WBiNoZ/INoS/ 761/10-12. We are very thankful to numerous students and staff members of the Jagiellonian University for their assistance in the fieldwork as well as to Alexander Radchenko for help with ant species identification and two anonymous reviewers for their constructive comments on earlier version of the manuscript.

Open Access This article is distributed under the terms of the Creative Commons Attribution License which permits any use, distribution, and reproduction in any medium, provided the original author(s) and the source are credited.

\section{References}

Baccaro FB, Ketelhut SM, De Morias JW (2010) Resource distribution and soil moisture content can regulate bait control in an ant assemblage in Central Amazonian forest. Austral Ecol 35:274-281

Batáry P, Örvössy N, Körösi Á, Vályinagy M, Peregovits L (2007) Microhabitat preferences of Maculinea teleius (Lepidoptera: Lycaenidae) in a mosaic landscape. Eur J Entomol 104:731-736

Batáry P, Körösi Á, Örvössy N, Kover S, Peregovits L (2009) Species-specific distribution of two sympatric Maculinea butterflies across different meadow edges. J Insect Conserv 13: $223-230$ 
Benton TG, Vickery JA, Wilson JD (2003) Farmland biodiversity: is habitat heterogeneity the key? Trends Ecol Evol 18:182-188

Beven KJ, Kirkby MJ (1979) A physically based, variable contributing area model of basin hydrology. Hydrolog Sci Bull 24:43-69

Bielański AK (1997) Materiały do historii powodzi w dorzeczu górnej Wisły. Politechnika Krakowska, Monografia 217, Kraków

Burmeier S, Donath TW, Otte A, Eckstein RL (2010) Rapid burial has differential effects on germination and emergence of small-and large-seeded herbaceous plant species. Seed Sci Res 20:189-200

Cowie J (2007) Climate change: biological and human aspects. Cambridge University Press, Cambridge, p 487

Czechowski W, Radczenko A, Czechowska W (2002) The ants (Hymenoptera, Formicidae) of Poland. MIZ PAN, Warsaw

Dierks A, Fischer K (2009) Habitat requirements and niche selection of Maculinea nausithous and M. teleius (Lepidoptera: Lycaenidae) within a large sympatric metapopulation. Biodivers Conserv 18:3663-3676

Eastman JR (1997) Idrisi for Windows. User's Guide Version 2.0. Clark University, Worchester, MA, USA

Elmes GW, Thomas JA, Wardlaw JC, Hochberg ME, Clarke RT, Simcox DJ (1998) The ecology of Myrmica ants in relation to the conservation of Maculinea butterflies. J Insect Conserv 2:67-78

Fronzek S, Carter TR, Jylhä K (2012) Representing two centuries of past and future climate for assessing risks to biodiversity in Europe. Glob Ecol Biogeogr 21:19-35

Gibbs M, Wiklund C, Van Dyck H (2011) Temperature, rainfall and butterfly morphology. Does life history theory match the observed pattern? Ecography 34:336-344

Hochberg ME, Clarke RT, Elmes GW, Thomas JA (1994) Population dynamic consequences of direct and indirect interactions involving a large blue butterfly and its plant and red ant hosts. J Anim Ecol 63:375-391

Hölzel N, Otte A (2004) Assessing soil seed bank persistence in flood-meadows: the search for reliable traits. J Veg Sci 15:93-100

IUCN (2012) IUCN red list of threatened species. Version 2012.2. $<w w w . i u c n r e d l i s t . o r g>$. Downloaded on 28 April 2013

Joy J, Pullin AS (1997) The effects of flooding on the survival and behaviour of overwintering large heath butterfly Coenonympha tullia larvae. Biol Conserv 82:61-66

Joy J, Pullin AS (1999) Field studies on flooding and survival of overwintering large heath butterfly Coenonympha tullia larvae on Fenn's and Whixall Mosses in Shropshire and Wrexham, UK. Ecol Entomol 24:426-431

Konvička M, Nedvěd O, Fric Z (2002) Early-spring floods decrease the survival of hibernating larvae of a wetland-inhabiting population of Neptis rivularis (Lepidoptera: Nymphalidae). Acta Zool Hung 48:79-88

Kowalska A (2009) Changes in the nature and spatial distribution of plant communities in the Middle Vistula Valley in the second half of the 20th century (as exemplified by the stretch of river between Annopol and Góra Kalwaria) I [Zmiany charakteru i rozmieszczenia zbiorowisk roślinnych $\mathrm{w}$ dolinie środkowej Wisły w drugiej polowie XX wieku (odcinek Annopol-Góra Kalwaria)]. Przeglad Geograficzny 81:347-364

Maes D, Van Dyck H (2001) Butterfly diversity loss in Flanders (north Belgium): Europe's worst case scenario? Biol Conserv 99:263-276

Nichols CN, Pullin AS (2000) A comparison of larval survivorship in wild and introduced populations of the large copper butterfly (Lycaena dispar batavus). Biol Conserv 93:349-358

Nowicki P, Vrabec V (2011) Evidence for positive density-dependent emigration in butterfly metapopulations. Oecologia 167:657-665

Nowicki P, Richter A, Glinka U, Holzschuh A, Toelke U, Henle K, Woyciechowski M, Settele J (2005a) Less input same output- simplified approach for population size assessment in Lepidoptera. Popul Ecol 47:203-212

Nowicki P, Settele J, Thomas JA, Woyciechowski M (2005b) A review of population structure of Maculinea butterflies. In: Settele J, Kuhn E, Thomas JA (eds) Studies in the ecology and conservation of butterflies in Europe. Vol. 2. Species ecology along a European gradient: Maculinea butterflies as a model. Pensoft Publishers, Sofia, pp 144-149

Nowicki P, Witek M, Skórka P, Settele J, Woyciechowski M (2005c) Population ecology of the endangered butterflies Maculinea teleius and M. nausithous, and its implications for conservation. Popul Ecol 47:193-202

Nowicki P, Pepkowska A, Kudlek J, Skórka P, Witek M, Settele J, Woyciechowski M (2007) From metapopulation theory to conservation recommendations: lessons from spatial occurrence and abundance patterns of Maculinea butterflies. Biol Conserv 140:119-129

Nowicki P, Bonelli S, Barbero F, Balletto E (2009) Relative importance of density-dependent regulation and environmental stochasticity for butterfly population dynamics. Oecologia 161:227-239

Pan F, Peters-Lidard CD, Sale MJ, King AW (2004) A comparison of geographical information systems-based algorithms for computing the TOPMODEL topographic index. Water Resour Res 40:W063031-W0630311

Plum N (2005) Terrestrial invertebrates in flooded grassland: a literature review. Wetlands 25:721-737

Pociask-Karteczka J (1994) Przemiany stosunków wodnych na obszarze Krakowa, [w:] B. Obrębska-Starklowa (red.), Przemiany środowiska geograficznego Krakowa i ich skutki, Zesz. Nauk. UJ, 1144, Prace Geograficzne 96:7-53

Robinson RA, Sutherland WJ (2002) Post-war changes in arable farming and biodiversity in Great Britain. J Appl Ecol 39:157-176

Saarinen K, Lahti T, Marttila O (2003) Population trends of Finnish butterflies (Lepidoptera: Hesperioidea, Papilionoidea) in 1991-2000. Biodivers Conserv 12:2147-2159

Settele J, Kuhn E, Thomas JA (eds) (2005) Studies in the ecology and conservation of butterflies in Europe. Vol 2. Species ecology along a European gradient: Maculinea butterflies as a model. Pensoft Publishers, Sofia

Settele J, Kudrna O, Harpke A, Kühn I, Van Swaay C, Verovnik R, Warren M, Wiemers M, Hanspach J, Hickler T, Kühn E, Van Halder I, Veling K, Vliegenthart A, Wynhoff I, Schweiger O (2008) Climatic risk Atlas of European Butterflies. Pensoft, Sofia, p 710. [BioRisk 1 (Special Issue): 1-710.] Open access at: http://pensoftonline.net/biorisk/index.php/journal/issue/current

Severns PM, Boldt L, Villegas S (2006) Conserving a wetland butterfly: quantifying early lifestage survival through seasonal flooding, adult nectar, and habitat preference. J Insect Conserv 10:361-370

Śliwińska EB, Nowicki P, Nash DR, Witek M, Settele J, Woyciechowski M (2006) Morphology of caterpillars and pupae of European Maculinea species (Lepidoptera: Lycaenidae) with an identification table. Entomol Fennica 17:351-358

SPSS Inc. (2010) IBM SPSS advanced statistics 19. SPSS Inc., Chicago

Tartally A, Varga Z (2008) Host ant use of Maculinea teleius in the Carpathian Basin (Lepidoptera: Lycaenidae). Acta Zool Acad Sci H 54:257-268

Thomas JA (1984) The behaviour and habitat requirements of Maculinea nausithous (the dusky large blue butterfly) and $M$. teleius (the scarce large blue) in France. Biol Conserv 28:325-347

Thomas JA, Settele J (2004) Butterfly mimics of ants. Nature 432:283-284 
Thomas JA, Elmes GW, Wardlaw JC, Woyciechowski M (1989) Host specificity among Maculinea butterflies in Myrmica ant nests. Oecologia 79:452-457

Thomas JA, Clarke RT, Elmes GW, Hochberg ME (1998) Population dynamics in the genus Maculinea (Lepidoptera: Lycaenidae). In: Dempster JP, McLean IFG (eds) Insect population dynamics in theory and practice. Symposia of the royal entomological society 19. Chapman \& Hall, London, pp 261-290

Thomas JA, Simcox DJ, Clarke RT (2009) Successful conservation of a threatened Maculinea butterfly. Science 325:80-83

Truxa C, Fiedler K (2012) Down in the flood? How moth communities are shaped in temperate floodplain forests. Insect Conserv Diver 5:389-397

Van Buskirk J, Willi Y (2004) Enhancement of farmland biodiversity within set-aside land. Conserv Biol 18:987-994

Van Swaay C (2012) Dos and don'ts for butterflies of the habitats directive of the European Union. Nat Conserv 1:73-153

Van Swaay CAM, Van Strien AJ, Harpke A, Fontaine B, Stefanescu C, Roy D, Maes D, Kühn E, Õunap E, Regan E, Švitra G, Heliölä
J, Settele J, Warren MS, Plattner M, Kuussaari M, Cornish N, Garcia Pereira P, Leopold P, Feldmann R, Jullard R, Verovnik R, Popov S, Brereton T, Gmelig Meyling A, Collins S (2010) The European butterfly indicator for grassland species 1990-2009. Report VS2010.010, De Vlinderstichting, Wageningen

WallisDeVries MF (2004) A quantitative conservation approach for the endangered butterfly Maculinea alcon. Conserv Biol 18:489-499

Webb MR, Pullin AS (1998) Effects of submergence by winter floods on diapausing caterpillars of a wetland butterfly Lycaena dispar batavus. Ecol Entomol 23:96-99

Witek M, Śliwińska E, Skórka P, Nowicki P, Settele J, Woyciechowski M (2006) Polymorphic growth in larvae of Maculinea butterflies, as an example of biennialism in myrmecophilous insects. Oecologia 148:729-733

Witek M, Nowicki P, Śliwińska EB, Skórka P, Settele J, Schönrogge K, Woyciechowski M (2010) Local host ant specificity of Maculinea (Maculinea) teleius butterfly, an obligatory social parasite of Myrmica ants. Ecol Entomol 35:557-564 